\title{
Firms Growth Strategies in Greece - The Case of KriKri S.A
}

\author{
Ioanna Dimitrakaki
}

Independent Researcher, Kioutachias 16 Serres, Greece.

Email: iondimi@hotmail.com Tel:6983728696

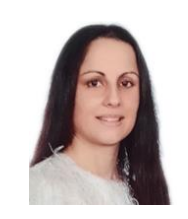

\begin{abstract}
The aim of this project was to examine firms' growth strategies followed by Greek enterprises, focusing in the case of KriKri SA: a firm that produces dairy products located in Serres, a province of North Greece. The analysis was based exclusively in the usage of secondary data. The result indicated that KriKri follows four types of growth strategies, namely: 1) Market penetration, 2) New product development, 3) Diversification, and 4) International Growth. The firm has successfully implemented the aforementioned practices and this is reflected in its overall business performance (Sales, Profits, EBITDA, etc.). In conclusion, the project highlighted the importance of growth for firms and organizations as a key element for increasing their profitability and ensuring their viability. It is also indicative that the firm achieved a substantial growth despite the economic crisis that affected negatively the Greek economy (OECD, 2021) and the appearance of the COVID 19 outbreak.
\end{abstract}

Keywords: Development strategies, Penetration, Differentiation, New product, Redemption-joint venture, Innovation, Performance, Classification, Profitability, Sustainability.

\section{Contribution of this paper to the literature}

This study contributes to existing literature by examine firms' growth strategies followed by Greek enterprises.

\section{Introduction}

The aim of this project was to examine firms' growth strategies followed by Greek enterprises, focusing in the case of KriKri SA, which is a firm that produces dairy products located in Serres, a province of North Greece. The study includes five sections that outline: an analysis of the academic theory that is relevant with the importance of growth in the firms' context, research methods followed by the author in the current study, an analysis of the case of KriKri and the conclusions of the project.

\section{Literature Review - Firms' Growth Theory}

As it is stated by Doyle (2000) growth strategies play an essential role for firms and organizations, since they determine their future viability. Doyle (2000) adds that corporate growth creates value for shareholders by increasing the future level of cash flow, accelerating the level of cash flow, extending the duration or reducing the risks attached to future returns. For that purposes, Doyle (2000) developed an integrated model that is called the "growth ladder", which shows the steps that a firm should follow for achieving growth (see Figure 1).

As shown above, the model distinguishes 9 strategies of corporate growth that should be followed gradually. Since one step is completed, the firm can move to the next one. These strategies are: 1) focus in increasing customer retention rate, 2) further development of customer's share, 3) acquire new buyers, 4) development of new products and/ore services, 5) entering new markets, 6) develop new distribution channels, 7) achieve international growth by entering into foreign markets, 8) make acquisitions and alliances and 9) achieve growth outside current industry boundaries. In sum, the model of Doyle (2000) gives emphasis in all the dimensions of marketing (product, price, distribution, communication) and indicates how they can be used for delivering value. For that reason, Doyle (2000) theory is called "value-based marketing".

Academics such as Ansoff (1957) developed a more concrete model that includes four main strategies of corporate growth. As shown in Figure 2, the model has the form of a matrix with two main dimensions: markets and products. Markets are distinguished in new and existing, whereas products are classified also in existing and new. According to these two dimensions, growth strategies are formulated as follows:

1. Market penetration: existing products in existing markets.

2. Product development: new products in existing markets.

3. Market development: existing products into new markets.

4. Diversification: new products in new markets. 


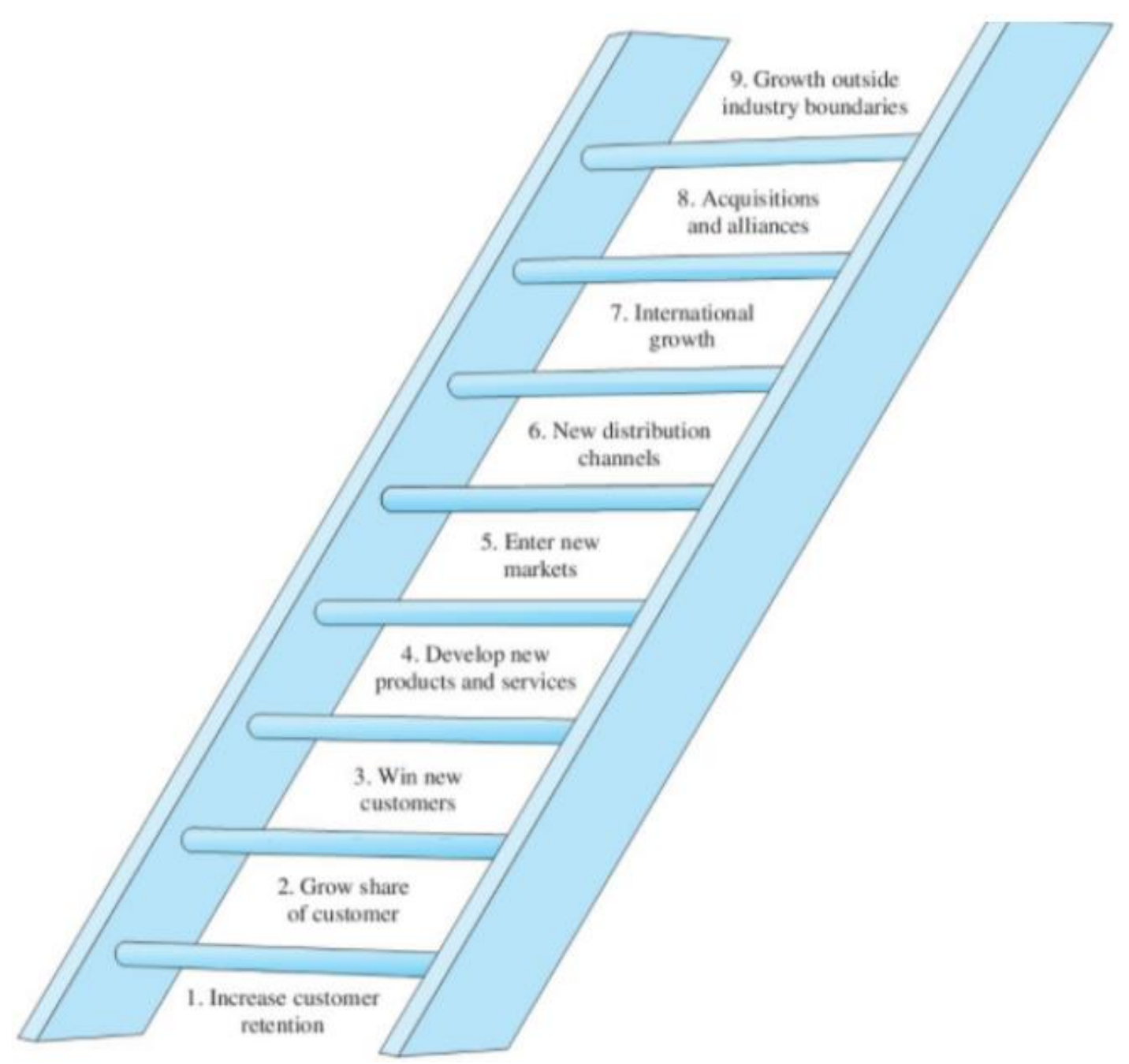

Figure 1. The ladder of growth, adapted from Doyle (2000).

\section{PRODUCTS}

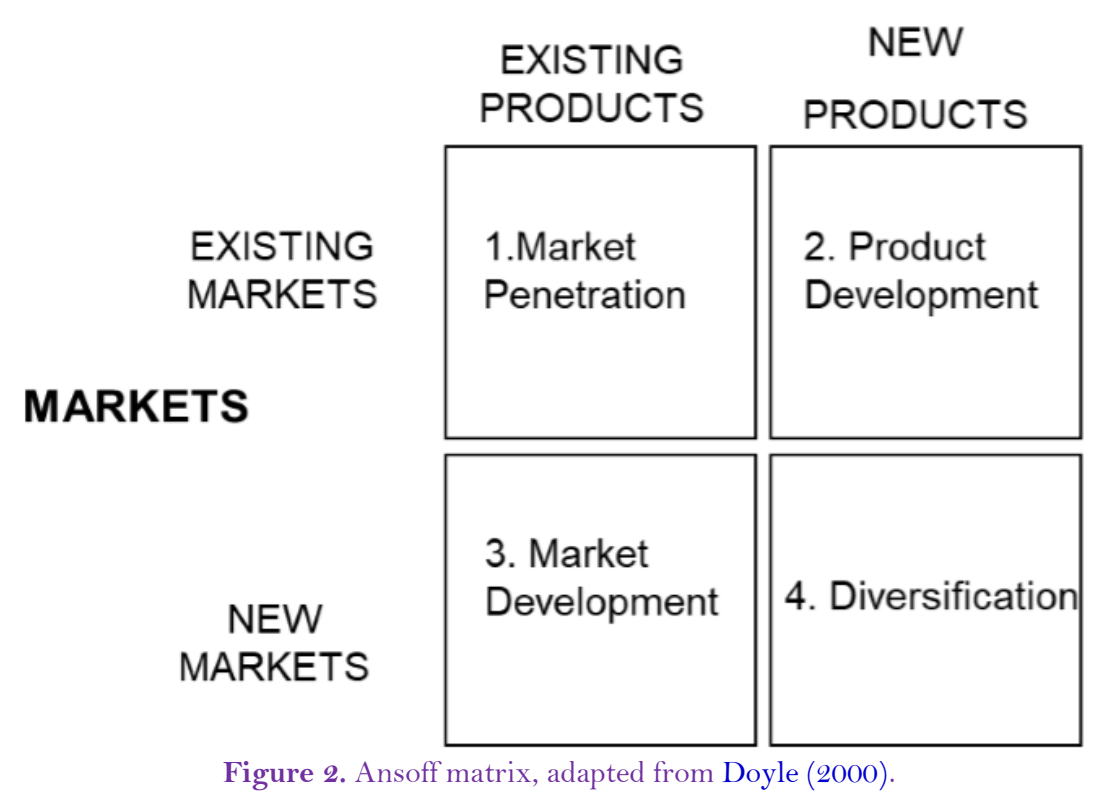

Market penetration strategies can be applied by: increasing purchase use of existing buyers, gaining customers from competitors and converting non users. Market development strategies are achieved mainly through entering in new market segments, developing new distribution channels and expanding in new geographic markets. Product development strategies prerequisite adding new features to existing products/services or developing new products. Lastly, diversification strategies cab be applied through organic growth, acquisitions and joint ventures (Schlegelmilch \& Winer, 2020).

Mascarenhas, Kumaraswamy, Day, and Baveja (2002) also examined growth strategies that were followed by firms and multinationals. The authors in their analysis classified five major strategies that lead to profitable and rapid growth, namely: 1) product proliferation, 2) mass market development, 3) increasing value to select customers strategy, 4) distribution innovation and 5) acquisition and consolidation strategies. Figure 3 shows the sources and illustrative examples of firms that applied each strategy. 


$\begin{array}{lll}\begin{array}{ll}\text { Sources of market } \\ \text { disequilibrium }\end{array} & \begin{array}{l}\text { Rapid technologi- } \\ \text { cal change creating }\end{array} & \text { A reconfigured } \\ \text { product revealing } \\ \text { products with } & \text { an unexpected } \\ \text { global demand } & \text { mass demand }\end{array}$

$\begin{array}{ll}\begin{array}{l}\text { Resulting growth } \\ \text { strategy }\end{array} & \begin{array}{l}\text { Product prolifera- } \\ \text { tion strategy }\end{array}\end{array}$

Mass market devel-
opment strategy
Challenge to mar- Demand pockets ket norms, reveal- underserved by ing that a broader market incumbents product scope tar- are exploited by geted to a narrower new entrants using customer base cre- distribution innoates more value vations

$\begin{aligned} & \text { Increasing value to } \\ & \text { select customers }\end{aligned}$
strategy

Deregulation encouraging acquisitions that tap new scale economies

\section{Acquisition and} consolidation strategy

Illustrative
examples

$\begin{array}{ll}\text { - Yahoo } & \text { - Sensar } \\ \text { - AOL } & \text { - Sabinsa } \\ \text { - PeopleSoft } & \text { - Starbucks } \\ \text { - Visio } & \text { - Nantucket } \\ \text { - Legato Systems } & \text { - Biogen } \\ \text { - Network } & \text { - Balance Bar } \\ \text { - Solutions } & \text { - Biovail } \\ \text { - Sycamore } & \text { - Vitesse Semi- } \\ \text { - Networks } & \text { conductors } \\ \text { - Analytical } & \text { - Salton } \\ \text { Graphics } & \end{array}$

Salton

- Atlantic Subsea

- Consumers Health

Network

- Syncro

- Aviation Sales

- Summa Industries

- Dover Downes

- Holt's Cigar

- Up and Away

- Dell Computer

- Sagemore Galleries

- Polymedica

- Acttrade International $\bullet$

Coach USA, Inc.

- Midcoast Energy Resources

- Family Golf Centers

- InnKeepers

- NCO Group

- USA Networks

- Infinity Broadcasting

- Dental Care Alliance

Source: Mascarenhas et al. (2002).

Figure 3. Five firm growth strategies.

To begin with, product proliferation can be implemented by: ensuring financial resources and funding in early stages, developing new products and services systematically mainly by investing in research and development, using efficiently marketing practices and methods, expanding to foreign markets, and giving emphasis in enhancing organizational and employee responsiveness. Examples of firms that followed the product proliferation paradigm are: Yahoo, AOL, PeopleSoft, Sycamore Networks, etc.

Moreover, mass market development strategy can be implemented by: focus in product segments that illustrate the highest market potential; converse resources for mass market development; reduce costs of production; use marketing techniques for supporting mass market protentional and increase the number of distribution channels that are used by the firm. Examples of firms that followed the mass market development strategy include: Starbucks, Biogen, Salton, etc.

To add value to selected customers firms should: develop metrics for detecting profitable buyer's segments, create, develop and sustain stable, profitable and long-term relationships with shoppers, and increase the value of current product offerings. Illustrative examples of firms that followed this growth strategy are: Atlantic Subsea, Consumers Health Network, Aviation Sales, Dover Downes, etc.

Distribution innovation strategy is applied by: analyzing the viability and the costs of new and alternative distribution networks, developing relationships with key suppliers, achieve economies of scale and focus on distribution innovation mainly through the usage of digital information systems. Examples of firms that followed these practices are Dell computer, Polymedica, etc.

Lastly, Acquisition and Consolidation strategy is implemented by: selecting ideal acquisition targets, developing new business models, refocusing acquisitions on market growth segments and empowering acquisition capabilities. Table 1 summarizes the main features of Mascarenhas et al. (2002) model by showing the scale, the scope and the time orientation of each growth strategy.

Finally, Eiriz, Faria, and Barbosa (2013) and Kang, Baek, and Lee (2021) support that firm's growth is mainly depended on innovation. Innovation is the key element that can drive enterprises to economic development. In this context, the authors developed a model (see Figure 4) that classifies innovation strategies. In particular, innovation can be applied to products or/and processes and is distinguished in incremental and radical. Therefore, four types of innovation are created that combine the following features:

1. Product development: it is incremental innovation in products.

2. Discovery: radical innovation in products.

3. Restructuring: radical innovation in processes.

4. Learning by experience: incremental innovation in processes.

In sum, companies should rely on the innovation strategy that fits to their needs for achieving economic growth (Kang et al., 2021). 
Table 1. Scale, scope and time orientation of firm growth strategies.

\begin{tabular}{|c|c|c|c|}
\hline \multirow[b]{2}{*}{ Strategy } & \multicolumn{3}{|c|}{ Source of advantage } \\
\hline & Scale & Scope & Time-based \\
\hline \multirow{2}{*}{$\begin{array}{l}\text { Product } \\
\text { proliferation }\end{array}$} & \multirow{2}{*}{$\begin{array}{l}\text { Low unit production and } \\
\text { distribution costs, global } \\
\text { demand }\end{array}$} & $\begin{array}{l}\text { Consistency and umbrella } \\
\text { brand across products }\end{array}$ & \multirow{2}{*}{$\begin{array}{l}\text { Early domination of product } \\
\text { Category, quick product development } \\
\text { and diffusion }\end{array}$} \\
\hline & & $\begin{array}{l}\text { Cross-selling products and } \\
\text { markets }\end{array}$ & \\
\hline \multirow[b]{2}{*}{$\begin{array}{l}\text { Mass market } \\
\text { development }\end{array}$} & \multirow[b]{2}{*}{$\begin{array}{l}\text { Reconfigure product to have } \\
\text { Mass market demand }\end{array}$} & Broaden geographic scope & Develop policies that travel \\
\hline & & $\begin{array}{l}\text { Outsource functions to } \\
\text { Reduce costs and increase } \\
\text { capacity }\end{array}$ & $\begin{array}{l}\text { Use alliances to hasten international } \\
\text { Expansion }\end{array}$ \\
\hline \multirow{2}{*}{$\begin{array}{l}\text { Increasing value to } \\
\text { select customers }\end{array}$} & & $\begin{array}{l}\text { Reduce geographic and } \\
\text { customer scope }\end{array}$ & \multirow{2}{*}{$\begin{array}{l}\text { Seize early the opportunity revealed } \\
\text { by challenging industry norms. }\end{array}$} \\
\hline & & $\begin{array}{l}\text { Adjust product scope to } \\
\text { increase customer value }\end{array}$ & \\
\hline \multirow{2}{*}{$\begin{array}{l}\text { Distribution } \\
\text { innovation }\end{array}$} & $\begin{array}{l}\text { Reduce transaction costs } \\
\text { with infrastructure } \\
\text { investment }\end{array}$ & \multirow{2}{*}{$\begin{array}{l}\text { Focus on underserved market } \\
\text { segments } \\
\text { Invest in new distribution } \\
\text { technologies }\end{array}$} & \multirow{2}{*}{$\begin{array}{l}\text { Exploit distribution innovation before } \\
\text { Incumbents can react }\end{array}$} \\
\hline & $\begin{array}{l}\text { Use geographical expansion } \\
\text { to Gain volume }\end{array}$ & & \\
\hline \multirow{4}{*}{$\begin{array}{l}\text { Acquisition and } \\
\text { consolidation }\end{array}$} & $\begin{array}{l}\text { Capture scale economies in } \\
\text { various functions Enabled } \\
\text { with larger firm size after } \\
\text { acquisitions }\end{array}$ & $\begin{array}{l}\text { Reorient acquisition towards } \\
\text { growth market segments }\end{array}$ & $\begin{array}{l}\text { Pursue acquisitions early to obtain } \\
\text { choise candidates }\end{array}$ \\
\hline & \multirow{3}{*}{$\begin{array}{l}\text { Develop relationships with } \\
\text { larger buyers and suppliers }\end{array}$} & $\begin{array}{l}\text { Reevaluate outsourcing } \\
\text { decisions in all functions after } \\
\text { acquisitions }\end{array}$ & \multirow{3}{*}{$\begin{array}{l}\text { Start integration process early to } \\
\text { hasten returns from acquisitions }\end{array}$} \\
\hline & & $\begin{array}{l}\text { Cross-sell products and } \\
\text { markets across acquisitions }\end{array}$ & \\
\hline & & $\begin{array}{l}\text { Invest in new technologies } \\
\text { that help to manage larger } \\
\text { film }\end{array}$ & \\
\hline
\end{tabular}

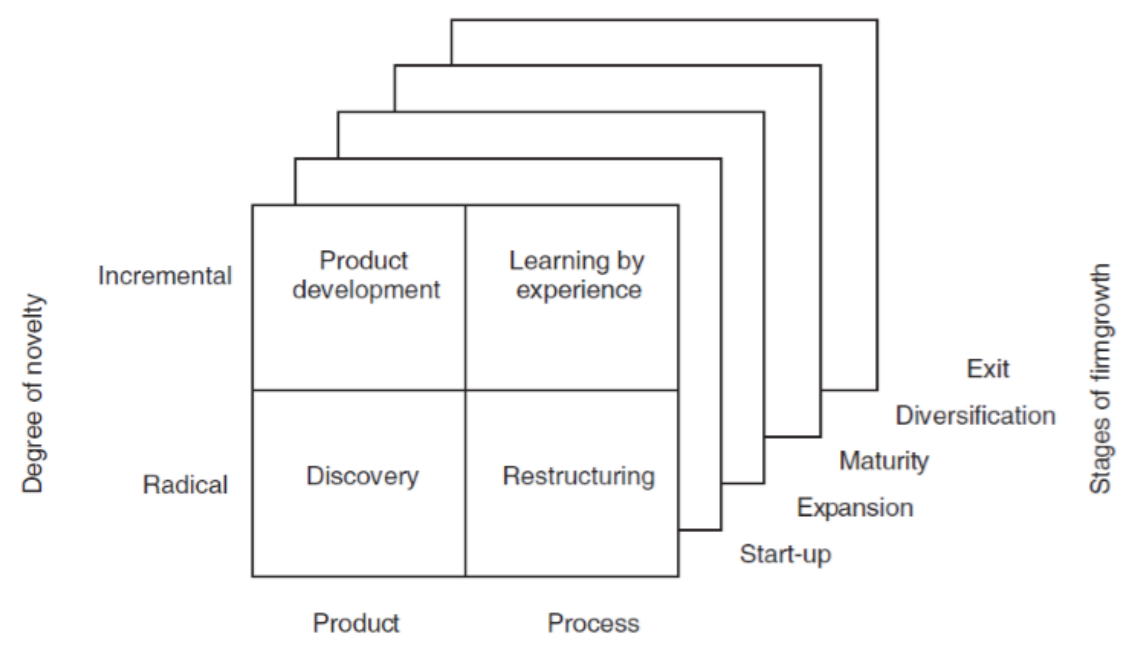

Type of innovation

Figure 4. Classification of innovation strategies that lead to enterprise growth. Source:Eiriz et al. (2013).

Table 2. Summary of literature review - classification of growth strategies for firms and organizations.

\begin{tabular}{l|l}
\hline \multicolumn{2}{c}{ Table 2. Summary of literature review - classification of growth strategies for firms and organizations. } \\
\hline Author & Typology of growth strategies \\
\hline Doyle (2000) & Increase customer retention rate \\
& Further development of customer's share \\
& Acquire new buyers \\
& Development of new products/services \\
& Entering new markets \\
& Develop new distribution channels \\
& International growth \\
& Acquisitions and alliances \\
& Growth outside current industry boundaries. \\
\hline Ansoff (1957) & Market penetration \\
& Product development \\
& Market development \\
& Diversification \\
\hline Mascarenhas et al. (2002) & Product proliferation \\
& Mass market development \\
& Increasing value to select customers strategy \\
& Distribution innovation \\
& Acquisitions and consolidations \\
\hline Eiriz et al. (2013); Kang et al. (2021) & Focus in innovation \\
& Product development \\
& Discovery \\
\hline & Restructuring \\
& Learning by experience \\
\hline
\end{tabular}


Table 2 summarizes the main findings of the literature analysis that was presented in this section. Findings are presented according to their source:

In conclusion, the analysis showed that there is a different typology of firm growth strategies mentioned in the literature. However, there are several common aspects in the classification mentioned by each researcher. Considering the growth strategies identified in the literature, in the next sections the author analyzes and evaluates the development practices followed by a certain Greek firm: KriKri S.A.

\section{Methods}

\subsection{Type of Research}

In business research there are two main types of research that derive from different research philosophies: positivism and interpretivist (Table 3). Each paradigm uses different research methods for addressing the examined scientific problems. The main difference between these two paradigms is that positivism focuses in measurement whereas interpretivist gives emphasis in understanding (Malhotra \& Birks, 2006; Saunders, Lewis, \& Thornhill, 2009). In the current project the interpretivist approach was used since the author attempted to understand the key drivers of firm growth strategies in the Greek market. The case study approach was used that is defined as follows: "The case study approach is a strategy for doing research which involves an empirical investigation of a particular contemporary phenomenon within its real-life context using multiple sources of evidence"(Robson, 2007).

The case that was analyzed was that of KriKri SA.

\subsection{Secondary Data}

The analysis was based exclusively in secondary data. Secondary data are defined as data that are previously gathered for some other purpose (Wrenn, Stevens, \& Loudon, 2007). Figure 5 shows the types of secondary data that are mentioned in the literature. Considering the model that is provided by Saunders et al. (2009) in the current project the author used: academic journals, organizations' surveys, data from organizations' web sites, industry statistics and reports, etc.

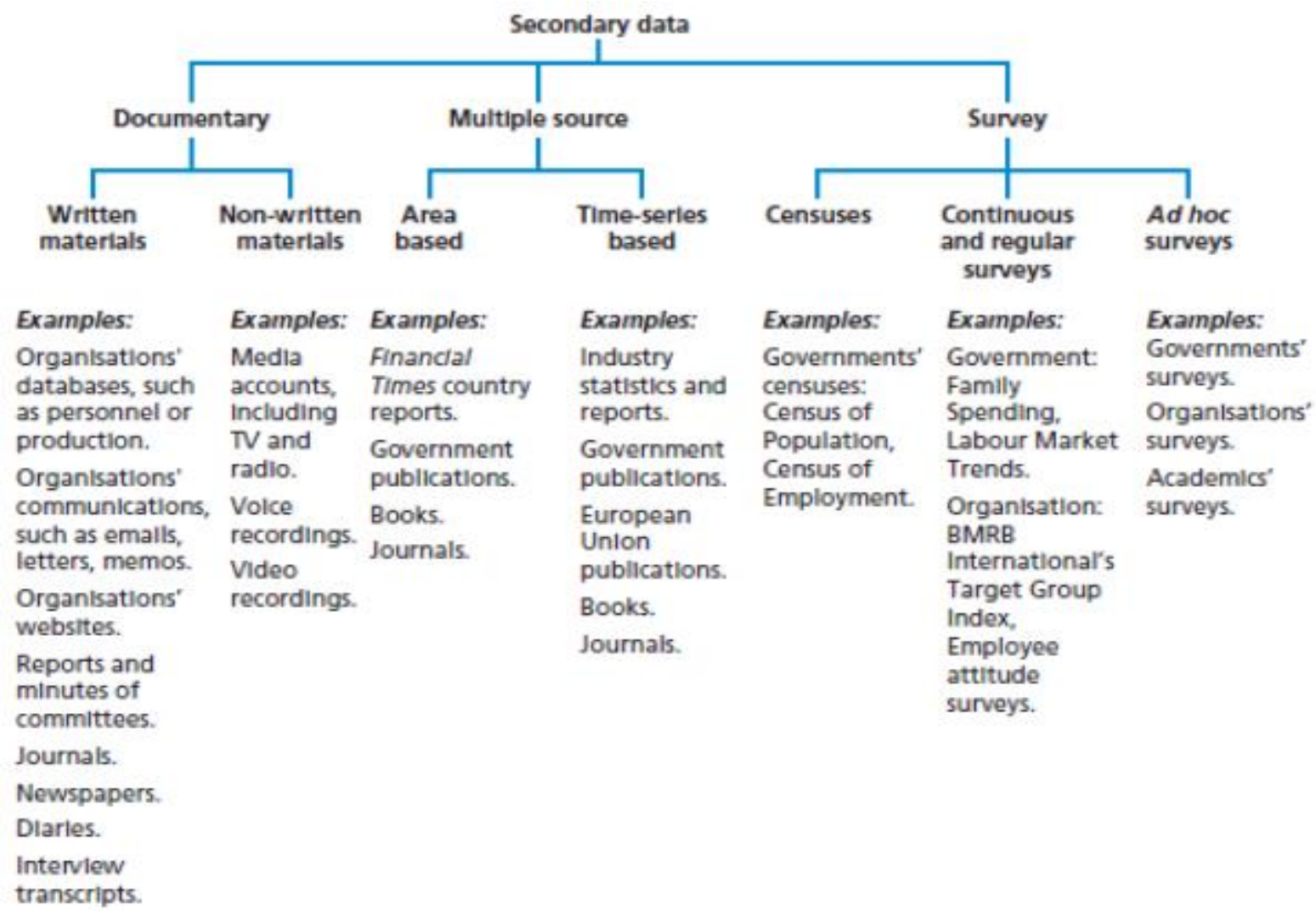

Figure 5. Types of secondary data.

\subsection{Limitations}

As it is for every study, the current project has certain limitations. In particular,

- The analysis was based exclusively in one firm. The examination of more cases would provide a more spherical view of the examined issues.

- The usage of secondary data involves disadvantages, such as: level of accuracy, timeliness of the information, quality, sufficiency and relatedness (Malhotra \& Birks, 2006; Malhotra. \& Birks, 2003).

- Firm growth strategies may be influenced by factors that were not mentioned in the current project.

\section{The Case of Kri-Kri}

\subsection{About the Company}

KriKri is a firm that produces dairy products located in Serres, a province of North Greece. The company focuses in two main markets: yogurt and ice creams. KriKri was founded in 1954 and nowadays sells its products in more than 35 countries. The vision of the firm is to develop and dynamically promote Greek food heritage throughout the world with love and respect to humans and to nature as well. The company operates two different production plants with state to the art machinery. The CEO of KriKri is Panagiotis Tsinavos. 
Table 3. Comparison betweenpositivism and interpretivist.

\begin{tabular}{|c|c|c|}
\hline Issue & Positivist & Interpretivist \\
\hline $\begin{array}{l}\text { Ontology: the researcher's view } \\
\text { of the nature of reality or being }\end{array}$ & $\begin{array}{ll}\text { External, objective } & \text { and } \\
\text { independent of social actors } & \end{array}$ & $\begin{array}{l}\text { Socially constructed, subjective, } \\
\text { may change, multiple }\end{array}$ \\
\hline $\begin{array}{l}\text { Epistemology: the researcher's } \\
\text { view regarding what constitutes } \\
\text { acceptable knowledge }\end{array}$ & $\begin{array}{l}\text { Only observable phenomena can } \\
\text { provide credible data and facts. }\end{array}$ & $\begin{array}{l}\text { Subjective meanings and social } \\
\text { phenomena. Focus upon the } \\
\text { details of situation }\end{array}$ \\
\hline Aim & $\begin{array}{l}\text { The aim is to measure the } \\
\text { examined problems }\end{array}$ & $\begin{array}{l}\text { The aim is to understand the } \\
\text { discussed phenomena }\end{array}$ \\
\hline Values & Value free $=$ unbiased & Value laden $=$ biased \\
\hline Research language & Formal and impersonal & Informal and personal \\
\hline Method & $\begin{array}{lll}\begin{array}{l}\text { Measurement of the } \\
\text { phenomena }\end{array} & \text { with } & \text { statistical } \\
\text { techniques } & & \\
\end{array}$ & $\begin{array}{l}\text { Hermeneutics- the required } \\
\text { information may be loosely } \\
\text { defined }\end{array}$ \\
\hline Theory and research design & $\begin{array}{l}\text { Simple determinist } \\
\text { Cause and effect } \\
\text { Static research design } \\
\text { Context free } \\
\text { Laboratory } \\
\text { Prediction and control } \\
\text { Reliability and validity } \\
\text { Representative surveys } \\
\text { Experimental design } \\
\text { Deductive }\end{array}$ & $\begin{array}{l}\text { Freedom of will } \\
\text { Multiple influences } \\
\text { Evolving design } \\
\text { Context bound } \\
\text { Field/ethnography } \\
\text { Understanding and insight } \\
\text { Perceptive decision making } \\
\text { Theoretical sampling } \\
\text { Case studies } \\
\text { Inductive }\end{array}$ \\
\hline Alternative names & $\begin{array}{l}\text { Quantitative } \\
\text { Objectivist } \\
\text { Scientific } \\
\text { Experimentalist } \\
\text { Traditionalist }\end{array}$ & $\begin{array}{l}\text { Qualitative } \\
\text { Subjectivist } \\
\text { Humanistic } \\
\text { Phenomenological } \\
\text { Revolutionist }\end{array}$ \\
\hline
\end{tabular}

\subsection{Business Model and Development Strategy}

Figure 6 shows the business model that is followed by KriKri. As shown below, the firm has developed an integrated framework that re-invests profits in order to develop further its operations. Moreover, the company gives particular emphasis in innovation and marketing initiatives for delivering high quality products to end users.

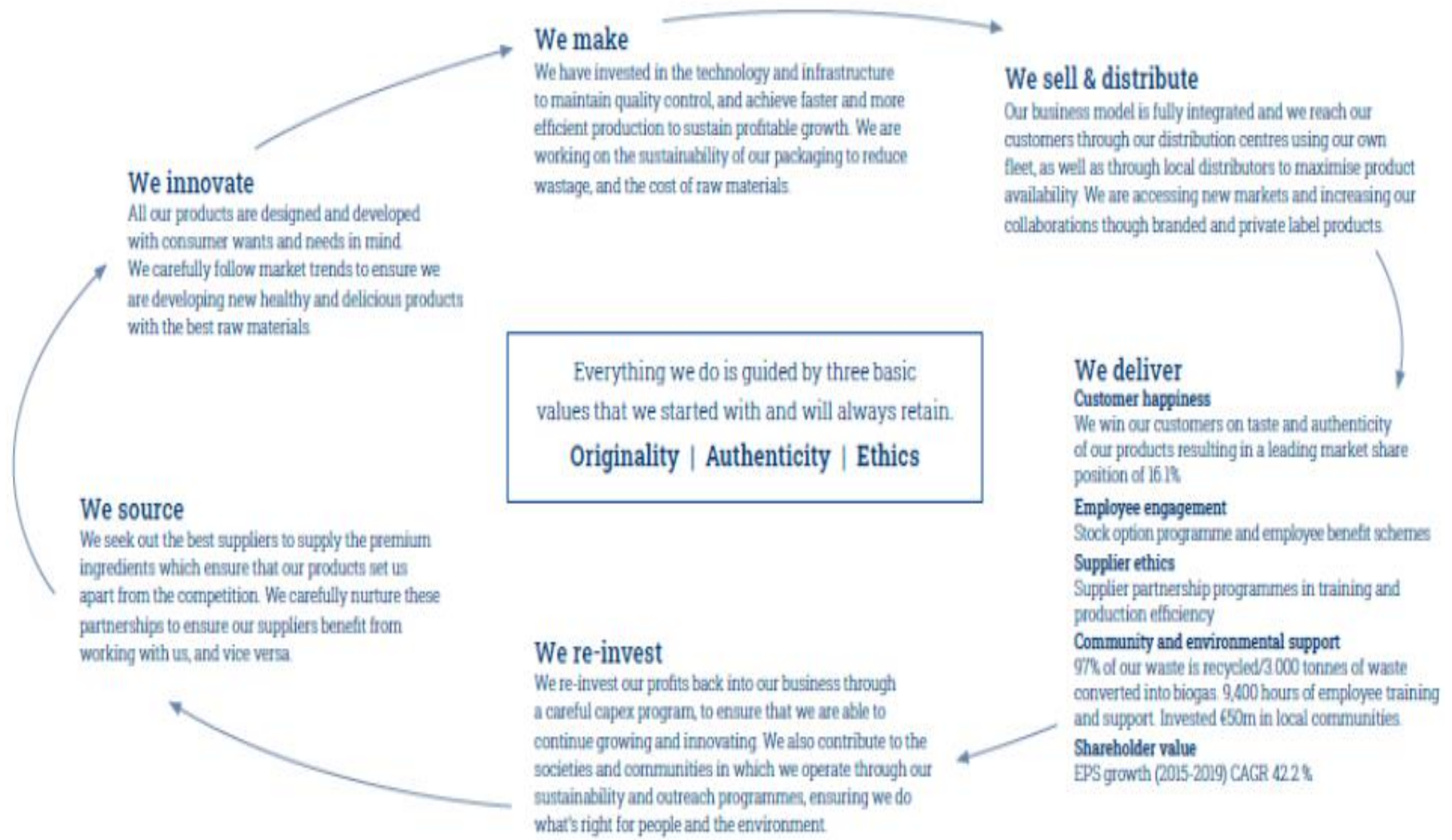

Figure 6. Business model of Kri-Kri.

Table 4 shows analytically the growth strategies that are followed by KriKri. Strategies are classified according to the type of the product (ice-cream and yogurt). In more details, the firm implements four types of growth strategies, namely: 1) Market penetration, 2) New product development, 3) Diversification, and 4) International Growth. Each strategy leads to certain actions. For example, in the yogurt market the firm developed new products such as lactose free and high protein yogurts that meet the needs of modern consumers that demand healthier foods with high nutrition value. One other crucial point of the growth strategies applied by KriKri is 
internationalization. The firm sells its products in more than 25 countries such as Italy, UK, France, Italy, Denmark, Finland, Cyprus, etc. Indicatively, Figure 7 shows the geographic footprint of the company.

Table 4. Growth strategies followed by KriKri.

\begin{tabular}{|c|c|c|}
\hline Product & Development strategy & Actions \\
\hline Branded Yogurt & Market penetration & $\begin{array}{l}\text { Maintain high margin levels } \\
100 \% \text { coverage of the market } \\
96 \% \text { brand awareness through efficient marketing practices } \\
\text { Competitive pricing }\end{array}$ \\
\hline Branded Yogurt & New product development & $\begin{array}{l}\text { Production of Lactose free products } \\
\text { High protein and super food yogurts } \\
\text { Yogurts for silver aged consumers } \\
\text { Production of kid's yogurts }\end{array}$ \\
\hline Branded Yogurt & Diversification & Entering into the Infant Yogurt category \\
\hline Ice cream & Market penetration & $\begin{array}{l}\text { Increase points of sales } \\
\text { Maintain high margin levels } \\
\text { Focus in Frozen Yogurt Line }\end{array}$ \\
\hline Ice cream & New product development & $\begin{array}{l}\text { New products that give emphasis in technology, packaging } \\
\text { and texture } \\
\text { Production of healthier ice-creams }\end{array}$ \\
\hline Yogurt and Ice cream & International Growth & $\begin{array}{l}\text { Selling products in more than } 25 \text { countries } \\
\text { Distribution in } 49 \text { supermarket chains } \\
42 \text { private label customers } \\
\text { More than } 21,000 \text { points of sales in the Ice cream market } \\
\text { Adjust products to local needs } \\
\text { Capture market trends } \\
\text { Focus in innovation } \\
\text { Adjust commercial and marketing tactics } \\
\text { Achieve differentiation in branded products }\end{array}$ \\
\hline
\end{tabular}

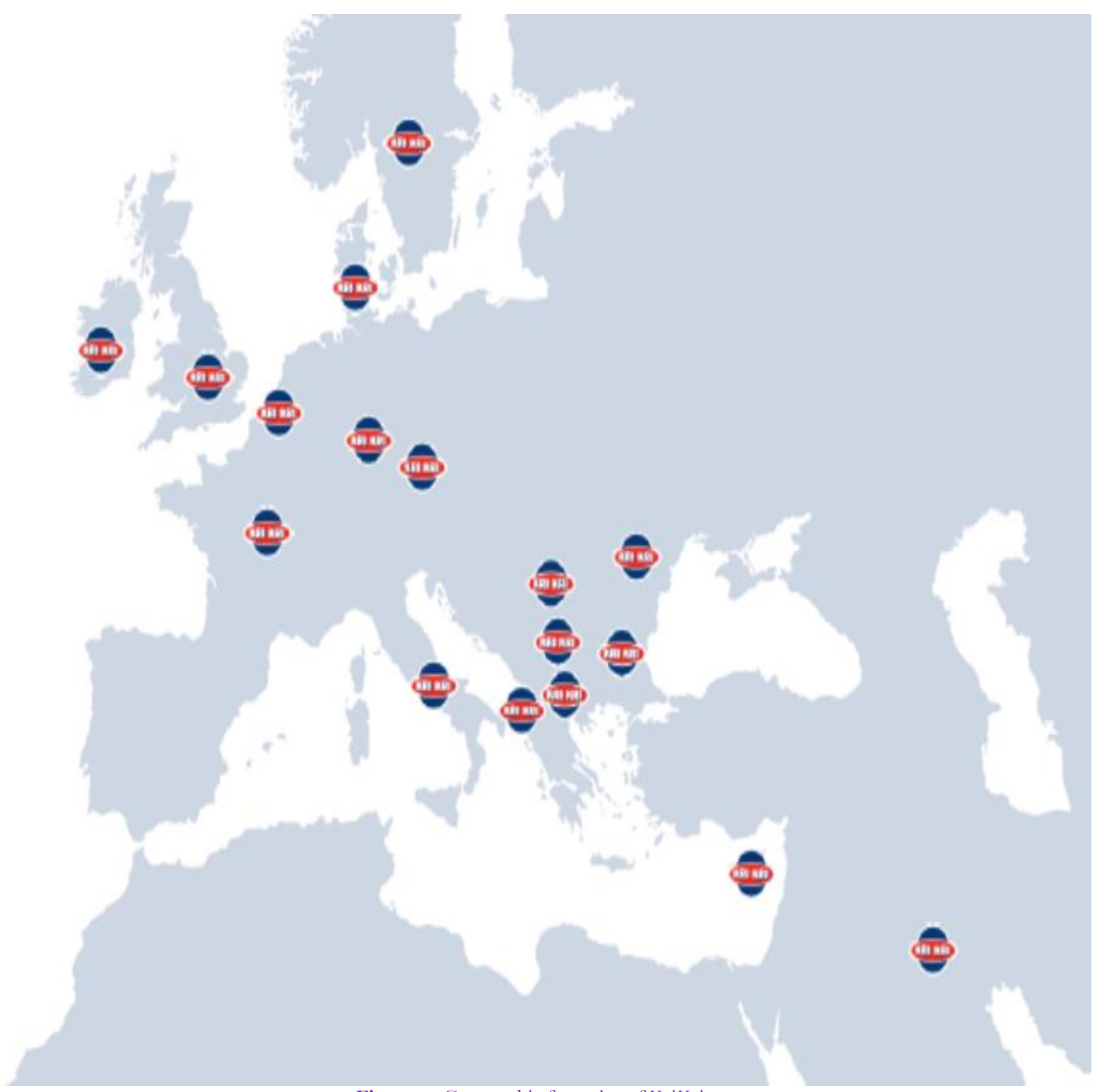

Figure 7. Geographic footprint of KriKri.

4.3. Performance of the Development Strategies Applied by Kri-Kri

In this paragraph the author evaluated the effectiveness of the development strategies followed by KriKri by analyzing the performance of the firm in sales, profits, etc. Firstly, Figure 8 shows sales evolution after 2016. As shown below, the firm managed to increase its sales by $88 \%$ in the period 2016-2020. 


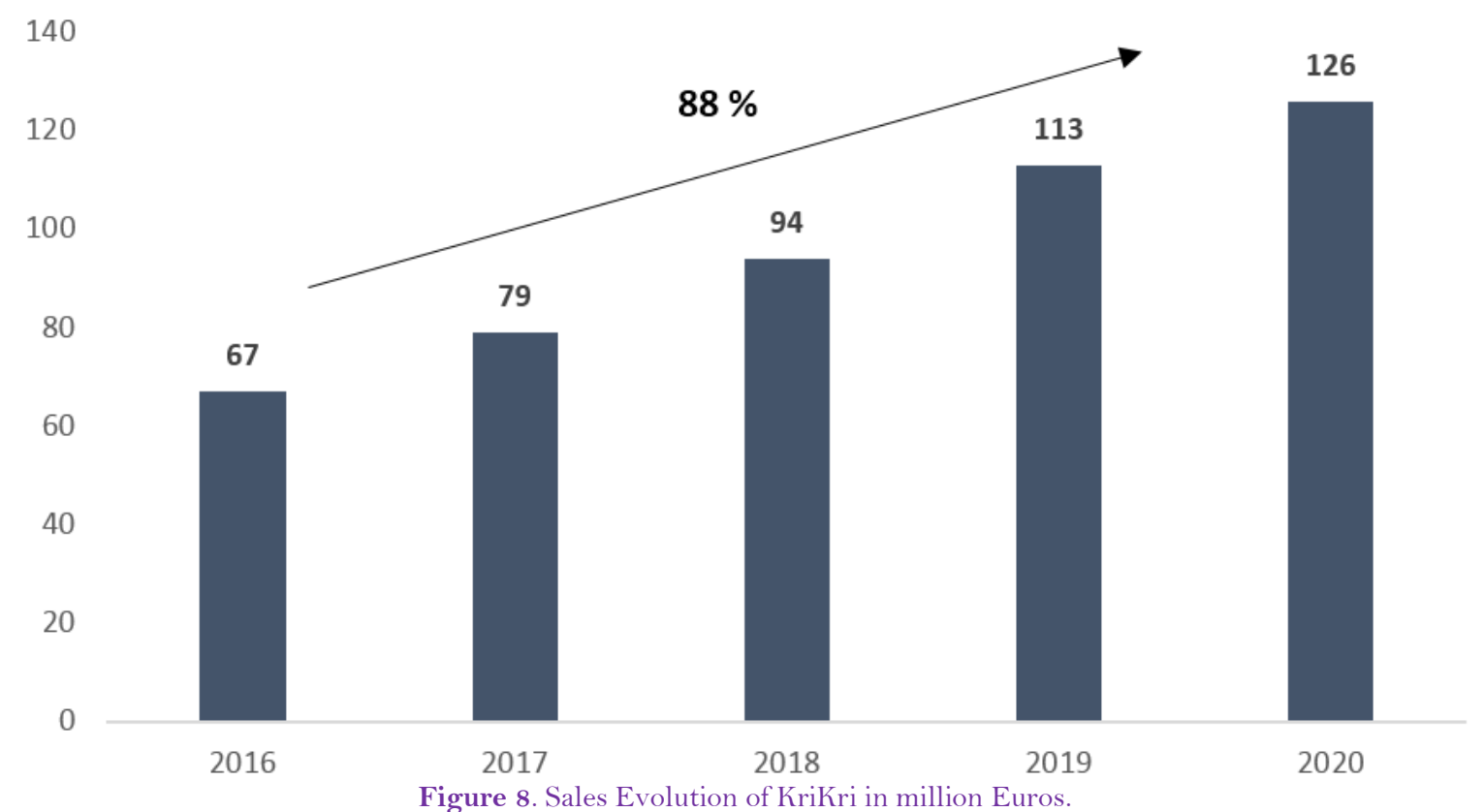

EBITDA (Earnings Before Interest, Tax, Depreciation, and Amortization) also increased by $105 \%$ in the same period, indicating the dynamics of the firm. In particular, in 2016 EBITDA were 10,9 million euros, whereas in 2020 were 22,3 million euros (see Figure 9).

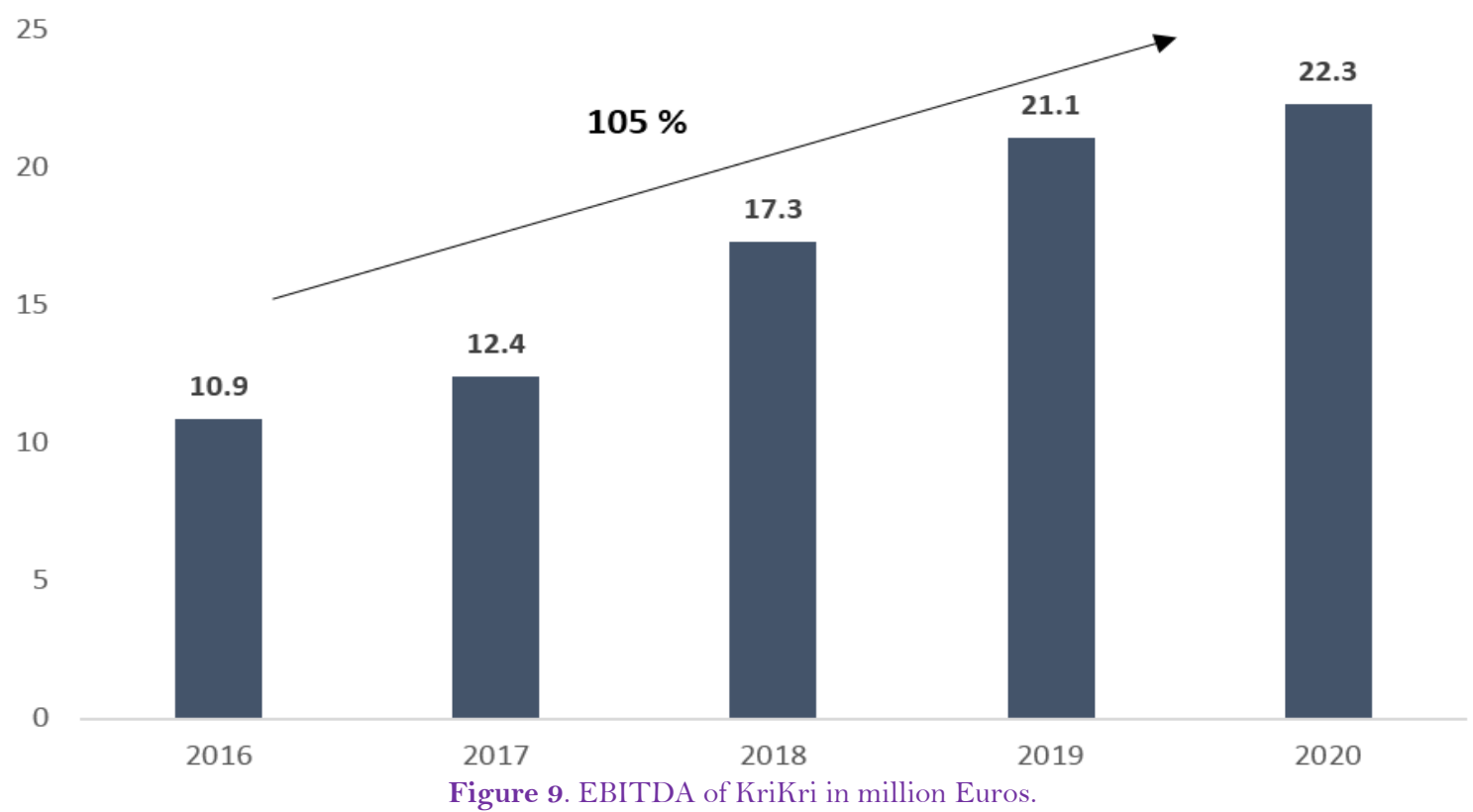

In the same length, Profits before taxes in the last five years increased by 124\% (see Figure 10). More specifically, in 2016 Profits were 8,2 million and in 2020 grew in 18,4 millions, despite COVID 19 outbreak.

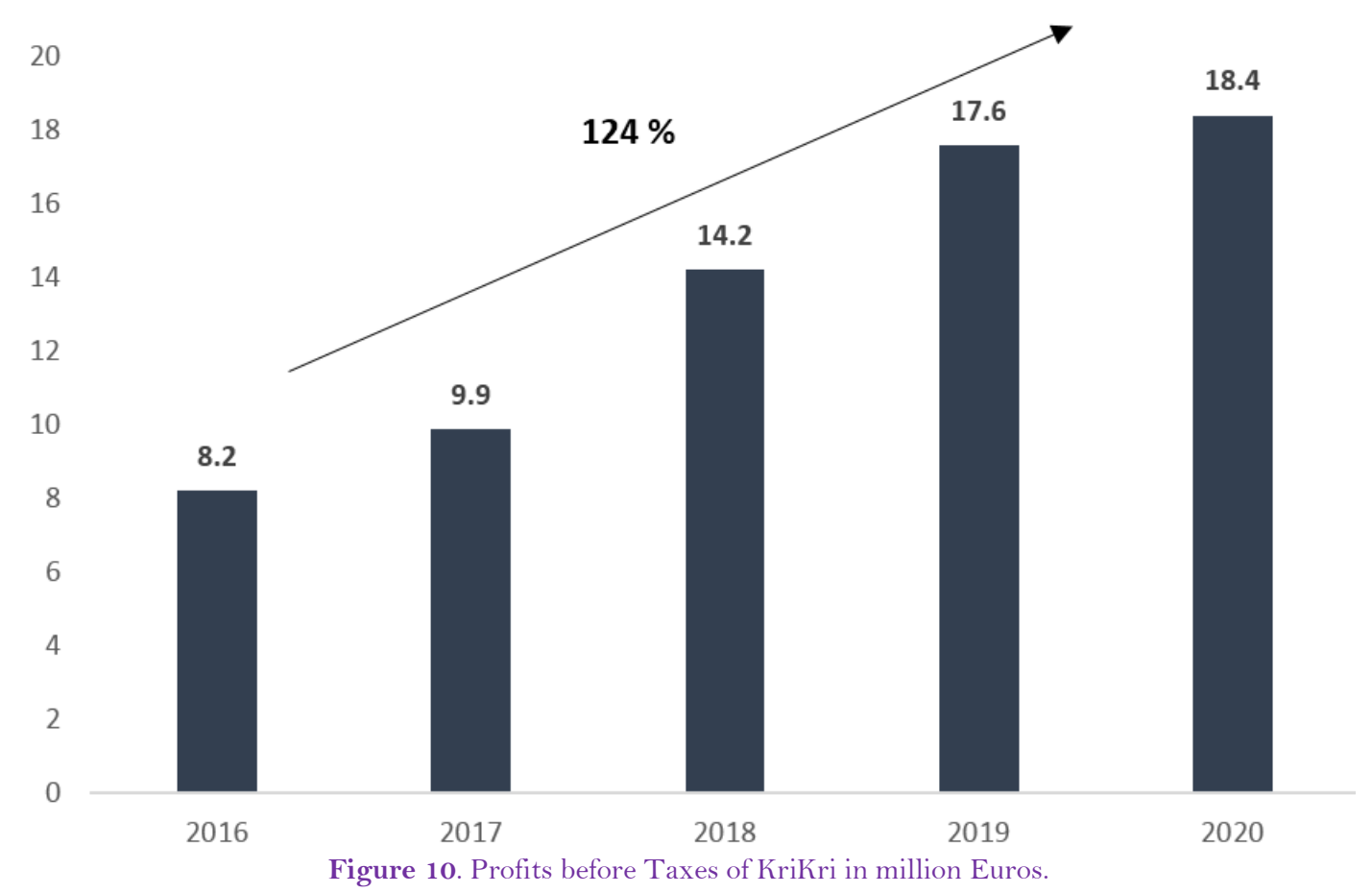


In the Greek market, sales of Yogurt after 2014 grew by $52 \%$. As shown in Figure 11, in 2014 yogurt sales were 33 million Euros and in 2020 climbed to 50 million euros.

55

50

45

40

35

30

33

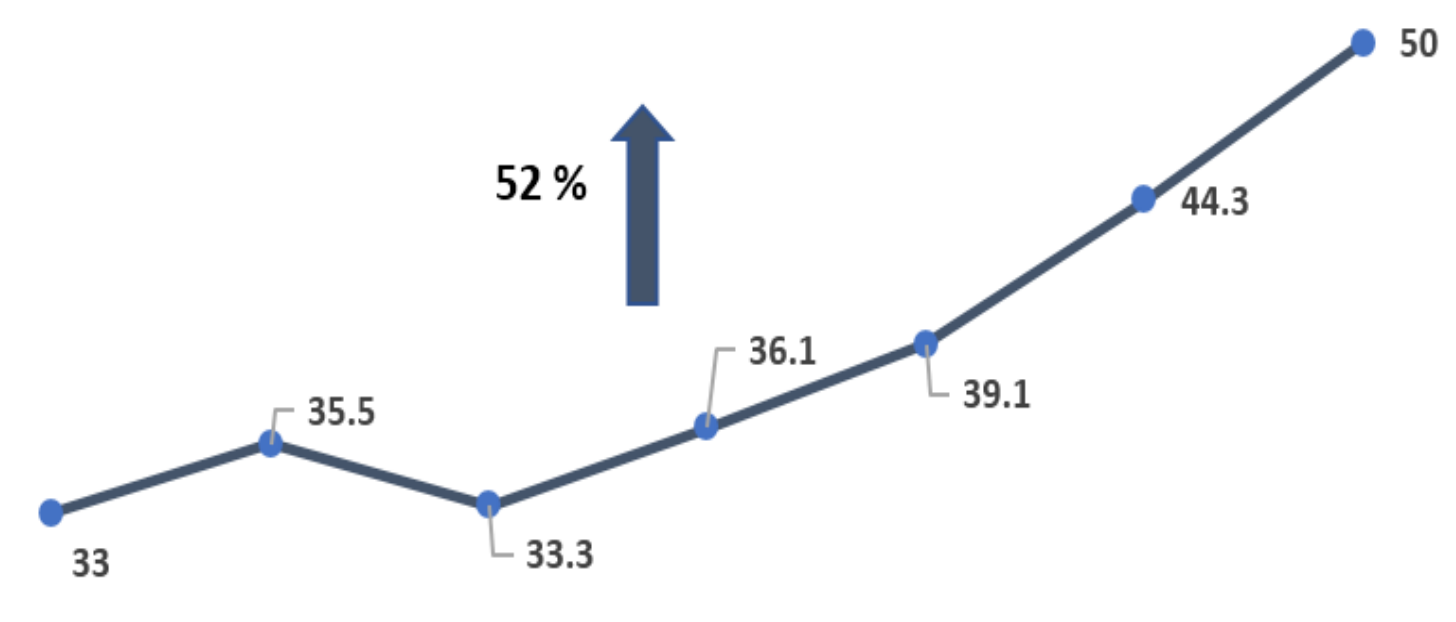

25

20

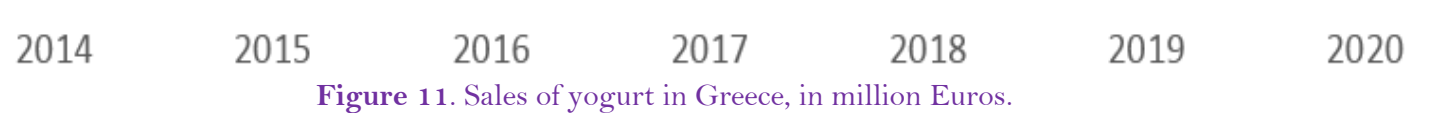

However, the most important growth rate was exhibited in the sales of yogurt in foreign markets. More particular, exports grew by $622 \%$, revealing that internationalization is one of the key development strategies of KriKri. In 2014, exports of yogurts were only 6,9 million, whereas in 2020 the value of exports was close to 50 million euros (see Figure 12).

60

50

40

$622 \%$

30

20
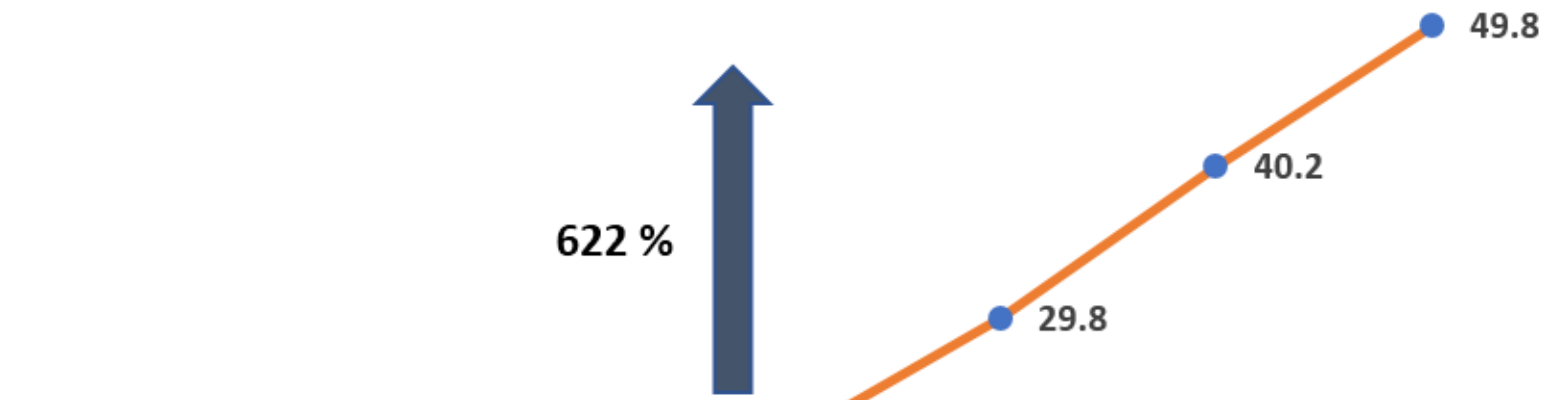

10

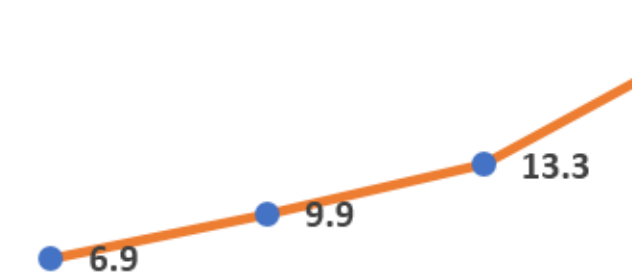

0

\begin{tabular}{|c|c|c|c|c|c|c|}
\hline 2014 & 2015 & 2016 & 2017 & 2018 & 2019 & 2020 \\
\hline
\end{tabular}

The only segment that illustrated decline was ice-creams in the domestic market. In more details, sales of icecreams slightly decreased (-1\%) in the period 2014-2010 (see Figure 13). Probably the Greek market is saturated but still the total turnover of the sector is fluctuated in satisfactory levels.

In contrast, exports of ice creams increased significantly (see Figure 14) in the last seven years. In 2014, the value of exports in the ice-cream market was 2,2 million euros, while in 2020 the value was 4,7 million euros. Exports reached in their highest levels in 2019. 
25

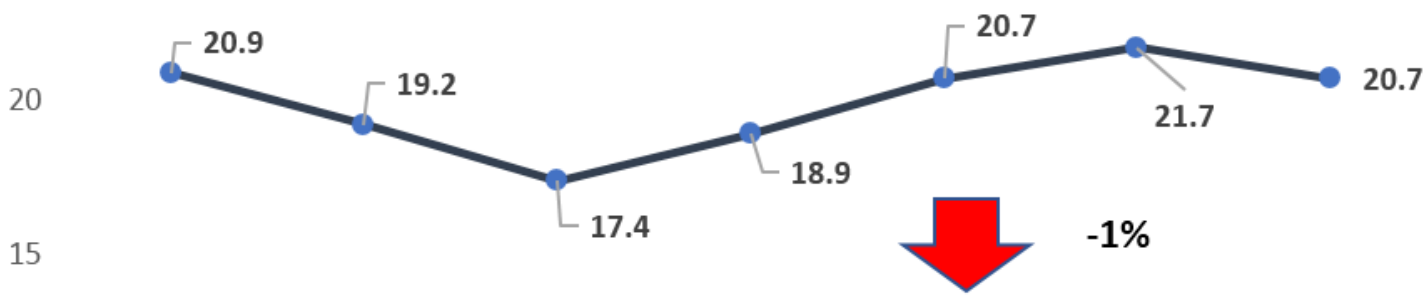

\begin{tabular}{|c|c|c|c|c|}
\hline 2015 & 2016 & 2017 & 2018 & 2019 \\
\hline
\end{tabular}

7

6

2

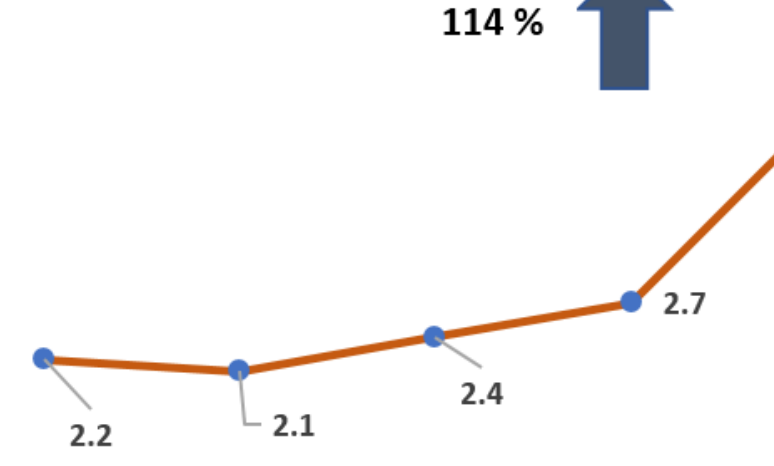

$114 \%$

1

0

$2015 \quad 2016$

016

2018

2019

2020

\section{Conclusions}

The aim of this project was to examine firm growth strategies followed by Greek enterprises, focusing in the case of KriKri SA. Firstly, the analysis indicated that there is a different typology of firm growth strategies mentioned in the literature. However, there are several common aspects in the classification mentioned by each researcher. Considering the growth strategies identified in previous studies, the empirical research showed that KriKri follows four types of growth strategies, namely: 1) Market penetration, 2) New product development, 3) Diversification, and 4) International Growth. The firm has successfully implemented the aforementioned practices and this is reflected in its overall business performance (Sales, Profits, EBITDA, etc.). In conclusion, the project highlighted the importance of growth for firms and organizations as a key element for increasing their profitability and ensuring their viability. It is also indicative that the firm achieved a substantial growth despite the economic crisis that affected negatively the Greek economy (OECD, 2021) and the appearance of the COVID 19 outbreak.

\subsection{Proposals}

The executives of the company KRI KRI are advised that they should not forget that in the modern international environment every company in order to survive with the rules of fierce competition, the products produced by the company must be accepted by the general consumer and in order to survive it is necessary to pump consumers beyond the borders of their country of origin and especially when the internal market is small or medium in size, such as Greece and the consumer public for a company the size of KRI KRI is limited and the strategies saturated positions.

\section{References}

Ansoff, H. I. (1957). Strategies for diversification. Harvard Business Review, 35(5), 113-124.

Doyle, P. (2000). Value based marketing. Chichester: Wiley and Sons.

Eiriz, V., Faria, A., \& Barbosa, N. (2013). Firm growth and innovation: Towards a typology of innovation strategy. Innovation, 15(1), 97-111. Available at: https://doi.org/10.5172/impp.2013.15.1.97. 
Kang, T., Baek, C., \& Lee, J.-D. (2021). Dynamic relationship between technological knowledge and products: Diversification strategy for firm growth. Technology Analysis $\mathcal{E}^{\circ}$ Strategic Management, 33(6), 653-669. Available at: https://doi.org/10.1080/09537325.2020.1834082.

Malhotra, N., \& Birks, D. (2006). Marketing research: An applied approach (3rd ed.). Harlow: Pearson Education.

Malhotra., N., \& Birks, D. (2003). Marketing research: An applied approach (2nd ed.). Harlow: Pearson Education.

Mascarenhas, B., Kumaraswamy, A., Day, D., \& Baveja, A. (2002). Five strategies for rapid firm growth and how to implement them. Managerial and Decision Economics, 23(4-5), 317-330. Available at: https://doi.org/10.1002/mde.1068.

Robson, C. (2007). The research of the real world, a tool for social scientists and professional researchers. Athens: Gutenberg Publications.

Saunders, M., Lewis, P., \& Thornhill, A. (2009). Research methods for business students (5th ed.). Upper Saddle River: Pearson Prentice Hall.

Schlegelmilch, B. B., \& Winer, R. S. (2020). The Routledge companion to strategic marketing. UK: Routledge.

Wrenn, B., Stevens, R., \& Loudon, D. (2007). Marketing research: Text and cases. New York: Haworth Publications.

\section{Internet sources:}

https://www.krikri.gr/home/

https://international.krikri.gr/

https://www.oecd.org/greece/

Citation | Ioanna Dimitrakaki (2021). Firms Growth Strategies in Greece - The Case of KriKri S.A. International Journal of Social Sciences and English Literature, 5: 1-11.

History:

Received: 22 November 2021

Revised: 24 December 2021

Accepted: 5 January 2022

Published: 14 January 2022

Licensed: This work is licensed under a Creative Commons

Attribution 3.0 License $\frac{(\mathrm{cc})}{\mathrm{Pr}}$

Publisher: Eastern Centre of Science and Education
Funding: This study received no specific financial support.

Competing Interests: The author declares that there are no conflicts of interests regarding the publication of this paper.

Transparency: The author confirms that the manuscript is an honest, accurate, and transparent account of the study; that no vital features of the study have been omitted; and that any discrepancies from the study as planned have been explained.

Ethical: This study followed all ethical practices during writing

Eastern Centre of Science and Education is not responsible or answerable for any loss, damage or liability, etc. caused in relation to/arising out of the use of the content. Any queries should be directed to the corresponding author of the article. 